\title{
Enticheioungen Ses
}

\section{(D)ber $=$ Seeamts und der Seeämter}

des

\section{Deutidhen Reidhs.}

Gerausgegeben

im

Reichsamt des Innern.

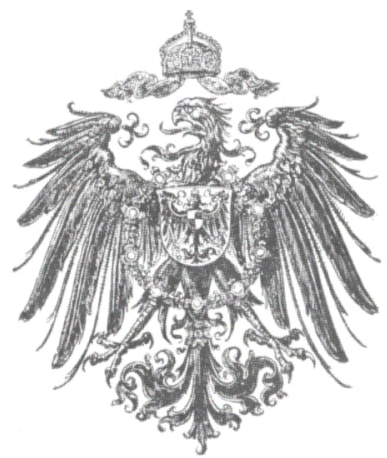

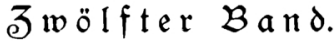

Geft 2 .

Gamburg.

Drua und Derlag von 5 friederiđten \& $\mathbb{C}_{0}$. 1897. 
